\title{
PENGARUH PROFITABILITAS, LIKUIDITAS DAN STRUKTUR AKTIVA TERHADAP STRUKTUR MODAL PADA PERUSAHAAN MANUFAKTUR YANG TERDAFTAR DI BURSA EFEK INDONESIA (BEI) PERIODE 2015-2017
}

\section{IMPACT OF PROFICIENCY, LIQUIDITY AND ACTIVATION STRUCTURES OF THE STRUCTURE OF CAPITAL ON A MANUFACTURING COMPANY LISTED IN THE INDONESIAN STOCK EXCHANGE (BEI) PERIOD 2015-2017}

\author{
Oki Oktaviana ${ }^{1}$, Jawida N.R Tampubolon ${ }^{2}$, Nina Purnasari ${ }^{3}$, \\ Jihan Safitri ${ }^{4}$, Mario Afandi P.W Manao ${ }^{5}$ \\ Universitas Prima Indonesia ${ }^{1,2,3,4,5}$ \\ okinapitupulu98@gmail.com ${ }^{1}$
}

\begin{abstract}
The manufacturing company is a product whose emphasis is on changing or processing raw materials, turning it into a half-finished product and into a marketable product that has commercial value. The management of companies' ability to increase corporate operations has had a crucial impact on increasing corporate profits. The study aims to understand the impact of proficiency (ROA), liquidity (CR), and the structure of capital structures on the manufacturing companies registered in the Indonesian stock exchange 2015-2017 period. In the study has a total of 70 of the population of 144 manufacturing companies, Implementing a secondary sampling method, and using secondary data drawn from the manufacturer's finance reports 2015-2017period. Linear regression analysis using test-F and test-t. From the result proves that profitability has little or no effect on capital structures while liquidity has no effect on capital structures and activation structures Significant to structuring capital. Researchers have simultaneously proven that independent variables consist of profitability, liquidity and activation structures do not simultaneously influence the dependent variables of capital structures.
\end{abstract}

Keywords : Profitability, Liquidity, Activation Structure and Capital Structure

\begin{abstract}
ABSTRAK
Perusahaan manufaktur merupakan perusahaan yang kengiatannya dalam mengubah atau mengelolah bahan dasar, menjadi produk setengah jadi dan menjadi suatu produk yang siap dipasarkan serta memiliki nilai jual. Kemampuan manajemen perusahaan untuk meningkatkan kegiatan operasional perusahaan memiliki pengaruh yang sangat penting untuk manaikkan profit perusahaan. Penelitian ini bermaksud supaya mampu memahami pengaruh profitabilitas (ROA), likuiditas (CR), dan struktur aktiva terhadap struktur modal pada perusahaan manufaktur yang terdaftar di Bursa Efek Indonesia (BEI) periode 2015-2017. Dalam penelitian ini memiliki total sample 70 dari jumlah populasi 144 perusahaan manufaktur, memakai metode purposive sampling, serta menggunakan data sekunder yang diambil dari laporan keuangan perusahaan manufaktur periode 2015-2017. Teknik analisis yang digunanakan yakni analisis regresi linear berganda dengan menggunakan uji-F dan uji-t. Dari hasil penelitian ini
\end{abstract}


membuktikan jika profitabilitas tidak berpengaruh atau tidak signifikan terhadap struktur modal, sedangkan likuiditas memiliki pengaruh negatif juga signifikan terhadap struktur modal, dan struktur aktiva tidak berpengaruh signifikan terhadap struktur modal. Dari hasil penelitian secara simultan membuktikan bahwa variabel independen terdiri dari profitabilitas, likuiditas dan struktur aktiva tidak berpengaruh secara simultan terhadap variabel dependen yaitu struktur modal.

Kata Kunci: Profitabilitas, Likuiditas, Struktur Aktiva dan Struktur Moda

\section{PENDAHULUAN}

Pada perekonomian saat ini banyak pesaing yang ingin lebih maju untuk mengembangkan usahanya. Sehingga pihak industri perlu berupaya dalam mengantisipasi persaingan yang semakin erat, baik bagi industri makro maupun mikro. Bagi industri harus mampu meningkatkan mutu dan kapasitas agar bisa bersaing dengan baik, sehingga upaya yang dilakukan tidak menjadi masalah bagi pihak industri

Industri manufaktur cukup berarti guna perekenomian di suatu negara. Dengan majunya sektor manufaktur mengindikasi adanya peningkatan ekonomi. Banyaknya sektor perusahaan manufaktur, menciptakan suatu pesaing yang ketat. Perusahaan manufaktur mulai meningkat, beberapa barangnya sudah berhasil mengendalikan bagian pemasaran di dunia. Diperkirakan pertumbuhan perekonomi Indonesia akan berada diposisi tiga besar setelah tiongkok dan india.

Dalam perusahaan permasalahan yang ada pada struktur modal sangat penting karena baik buruknya structure capital akan sangat berpengaruh pada kondisi keuangan perusahaan, yang sering terjadi ialah penggunaan utang lebih besar atas modal itu sendiri, maka beresiko pada kebangkrutan.

Perusahaan yang memiliki struktur modal mampu mengurangi beban penggunaan keseluruhan modal, perusahaan yang mampu memanifestasikan tingkat pengembalian yang maksimal dapat memaksimalkan struktur modalnya, maka tidak hanya perusahaan yang mendapatkan laba, namun para investor juga ikut mendapatkan labanya.

Masalah profitabilitas sangatlah penting bagi perusahaan karena besarnya tingkat kesanggupan perusahaan untuk memperoleh profit. Profitabilitas yang tinggi di perusahaan dapat mengait penyandang dana untuk berinvestasi dikarenakan profitabilitas menunjukan tingkat utang yang minim dengan sumber profit internal yang lebih. Hasil penelitian dari Widodo \& Djawahir (2014), Santoso \& Priantinah (2016) dan Eviani (2016) yang menyatakan bahwa Profitabilitas berpengaruh negatif dan signifikan terhadap Struktur modal.

Tingkat likuiditas yang tinggi pada perusahaan, menunjukkan masalah kemampuan dalam mengelola cash balance yang mengganggur, persediaan yang relatif eksesif, atau prosedur angsuran perusahaan yang kurang baik sehingga membuat tingginya tingkat piutang usaha. Hasil penelitian Wulandari (2013) yang menyatakan likuiditas berpengaruh negatif dan tidak signifikan terhadap struktur modal.

Suatu perusahaan yang menyandang tingkat struktur aktiva yang tinggi cenderung memanfaatkan substansi dari aspek eksternal maupun 
utang untuk memadai kepentingan modal. Tingginya tingkat penggunaan dana dari pihak ketiga akan mempengaruhi besar kecilnya laba yang dihasilkan perusahaan. Penelitian yang dilakukan oleh Farisa \& Widati (2017) dan Santoso \& Priantinah (2016) yang menyatakan bahwa Struktur Aktiva berpengaruh negatif dan tidak signifikan terhadap Struktur Modal.

\section{METODE PENELITIAN}

\section{Pendekatan Penelitian}

Pendekatan penelitian yang digunakan oleh peneliti adalah penelitian kuantitatif melalui situs www.idx.co.id. Observasi kuantitatif merupakan prosedur beralaskan prinsip positivisme, untuk meneliti data population dan sample yang terpilih, instrumen penelitian digunakan sebagai pengambilan data, menguji hipotesis yang telah ditentukan merupakan tujuan dari analisis data bersifat kuantitatif atau statistic

Variabel yang digunakan terdiri dari angka yang dapat dianalisis menurut prosedur statistik. Data berupa angka penelitian ini yakni data profitabilitas, likuiditas dan struktur aktiva pada industri manufaktur yang terdaftar di BEI periode 2015-2017.

\section{Jenis Penelitian}

Penelitian memakai pendekatan verikatif, ialah metode penelitian yang tujuanya demi memahami atau mengetahui jalinan kausalitas antara variabel menggunakan suatu pengujian, perhitungan statistick sihingga menghasilkan bukti yang menunjukkan hipotesis diterima atau ditolak.

\section{Populasi}

Population yaitu daerah abstraksi terdiri atas bahan/entitas yang menyandang mutu dan idiosinkrasi, yang ditentukan peneliti perlu dipelajari lantas ditarik kesimpulannya.
Perusahaan manufaktur yang terdaftar di BEI periode 2015-2017 digunakan sebagai populasi penelitian. Jumlah populasi penelitian sebanyak 144 perusahaan.

\section{Sampel}

Penelitian ini memakai prosedur purposive sampling. Purposive sampling merupakan metode yang menentukan sample lewat penilaian tertentu.

Beberapa kriteria yang ditentukan adalah:

ditentukan:

Beberapa kriteria yang

1. Industri manufaktur yang tercantum di BEI periode 2015-2017.

2. Perusahaan manufaktur yang mempubliskan secara detail laporan keuangan selama periode 20152017.

3. Industri manufaktur dapat memperoleh laba pada periode 2015-2017.

Dari total populasi 144 diseleksi menjadi data sample yang dipakai dalam penelitian berjumlah 70 perusahaan. Dan memperoleh jumlah data sebanyak 210 data. Data tersebut diperoleh dari (70 x 3 tahun).

\section{Penelitian Identifikasi dan Definisi Operasional Variabel}

Variabel yang digunakan atas penelitian terdiri oleh variabel partikelir dan terbatas. Variabel babas yaitu variabel yang berpengaruh sedangkan variabel terbatas ialah variabel yang mempengaruhi atau sebagai dampak atau konsekuensi, lantaran adanya variabel lepas. Variabel bebas pada penelitian ini meliputi profitabilitas $\left(\mathrm{X}_{1}\right)$, likuiditas $\left(\mathrm{X}_{2}\right)$, dan struktur aktiva $\left(\mathrm{X}_{3}\right)$. Sedangkan variabel terkait pada penelitian ialah struktur modal (Y). Penelitian ini menggunakan pengukuran 
skala ratio. Identifikasi dan defenisi operasional merupakan penjelasan penjelasan yang telah terpilih.

\section{Profitabilitas}

Profitabilitas ialah perbandingan yang mendeskripsikan kinerja satu perusahaan untuk mencapai profit lewat segala keahlian dan kompetensi yang dimiliki oleh perusahaan, yang bersumber dari penggunaan aktiva, pemakaian kapital, dan kengiatan penjualan. Mencari rumus ROA dapat digunakan dengan:

$$
\mathrm{ROA}=\frac{\text { Net Profit }}{\text { Total Asset }}
$$

\section{Likuiditas}

Likuiditas ialah rasio yang menilai kesanggupan suatu perusahaan akan menutup short term debt. Menurut Harahap (2015) rumus mencari Rasio lancar (CR) dapat menggunakan rumus, yaitu:

$$
\text { Rasio Lancar }=\frac{\text { Aktiva Lancar }}{\text { Utang Lancar }}
$$

\section{Struktur Aktiva}

Struktur aktiva yaitu penetapan luasnya distribusi current assets maupun fixed assets. Menjurus pada penelitian Rumus mencari Struktur aktiva dapat digunakan sebagai berikut:

$$
\text { Struktur Aktiva }=\frac{\text { AktivaTetap }}{\text { TotalAktiva }}
$$

\section{Struktur Modal}

Struktur modal ialah perbandingan masa pemakaian kapital pinjaman yang terdiri short term debt yang karekternya tetap, long term debt atas dana sendiri yang terdiri oleh preferred stock dan common stock.

Rumus yang dipakai untuk mengetahui struktur modal dengan menggunakan DER

$$
\text { Debt to Equity Ratio }=\frac{\text { Total Utang }}{\text { Ekuitas }}
$$

\section{Teknik Analisis Data}

Penelitian ini menggunakan analisis data metode regresi linear berganda didukung oleh program SPSS dalam pengolahan data. Fungsi dari metode ini untuk memahami implikasi/afiliasi variabel partikelir dengan variabel terbatas. Variabel bebas yaitu profitabilitas, likuiditas, dan struktur aktiva sedangkan variabel terikat ialah struktur modal.

\section{Analisis Regresi Linier Berganda}

Dipakai mengestimasikan satu variabel terkait berlandaskan dua atau beberapa variabel independen (Cahyani \& Handayani 2017). Untuk dapat mengetahui pengaruh variabel terbuka dan variabel terbatas dengan menggunakan analisis regresi linear berganda ialah :

$$
\mathrm{Y}=\mathrm{a}+\mathrm{b}_{1} \mathrm{X}_{1}+\mathrm{b}_{2} \mathrm{X}_{2}+\mathrm{b}_{3} \mathrm{X}_{3}+\mathrm{e}
$$

Keterangan:

Y : Struktur Modal

a : Constant

$b_{1}$ :Koefisien regresi variabel

$b_{2}$ : Koefisien regresi variabel $\mathrm{X}_{2}$ ( Likuiditas)

$b_{2}$ : Koefisien regresi variabel $\mathrm{X}_{3}$ ( Struktur Aktiva)

$\mathrm{X}_{1}$ : Profitabilitas

$\mathrm{X}_{2}$ : Likuiditas

$\mathrm{X}_{3}$ : Struktur Aktiva

e : Persentase Kesalahan/term of error $(5 \%)$

\section{Kofisien Determinan}

$$
\text { Pada hakikatnya }\left(\mathrm{R}^{2}\right)
$$

memperkirakan rentang kebolehan acuan ketika menjelaskan ragam variabel terkait. Nilai koefisien determinasi adjusted yaitu antara nol dan satu. 


\begin{abstract}
Pengujian Hipotesis secara $\operatorname{Simultan}($ Uji-F)

Pada dasarnya uji-F membuktikan bagaimana seluruh variabel bebas bertepatan memiliki pengaruh secara simultan pada variabel terikat.
\end{abstract}

\section{Pengujian Hipotesis secara Parsial} (Uji-t)

Tujuan uji-t memperlihatkan betapa pengaruhnya satu variabel bebas secara invidu saat menjelaskan ragam variabel terikat.

\section{HASIL DAN PEMBAHASAN Regresi Linier Berganda}

Tabel 1. Persamaan Regresi Linier Berganda

\begin{tabular}{|c|c|c|c|c|}
\hline & & Coeffic & $\mathrm{ts}^{\mathrm{a}}$ & \\
\hline & & $\begin{array}{l}\text { Unstanc } \\
\text { Coeff }\end{array}$ & $\begin{array}{l}\text { dized } \\
\text { ents }\end{array}$ & $\begin{array}{c}\text { Standardized } \\
\text { Coefficients }\end{array}$ \\
\hline & & $B$ & $\begin{array}{l}\text { Std. } \\
\text { Error }\end{array}$ & Beta \\
\hline & (Constant) &,- 277 & ,230 & \\
\hline & $\begin{array}{l}\text { LnProfitabil } \\
\text { itas }\end{array}$ &,- 078 & ,054 &,- 093 \\
\hline 1 & $\begin{array}{l}\text { LnLikuidita } \\
\mathrm{s}\end{array}$ &,- 555 & ,096 &,- 376 \\
\hline & $\begin{array}{l}\text { LnStruktur } \\
\text { Aktiva }\end{array}$ & ,006 & ,112 & ,003 \\
\hline
\end{tabular}
diperoleh bentuk persamaan regresi liniear berganda, yaitu:

\section{LnDER $=-\mathbf{0 , 2 7 7 - 0 , 0 7 8}$ \\ LnROA-0,555 LnCR+0,006 \\ LnSA} diartikan sb:

Dari persamaan tersebut bisa

1. Nilai constanta sebesar $-0,277$ satuan menjelaskan jika Return on Aset, Current Ratio, dan Struktur Aktiva bernilai constanta atau tetap maka struktur modal dominan 0,277

2. Nilai koefisien regresi Return on Aset $\left(\mathrm{X}_{1}\right)$ sebesar $-0,078$ bernilai negatif menjelaskan bila masingmasing peningkatan 1 satuan Retun on Aset akan mengakibatkan penurunan struktur modal dominan 0,078 .

3. Nilai koefisien regresi Current Ratio $\left(\mathrm{X}_{2}\right)$ dominan $-0,555$ bernilai negatif menjelaskan bila masing-masing peningkatan 1 satuan Current Ratio akan mengakibatkan depresiasi struktur modal sebesar -0,555.

4. Nilai koefisien regresi struktur aktiva $\left(\mathrm{X}_{3}\right)$ berjunlah 0,006 bernilai positif menjelaskan bila masingmasing peningkatan 1 satuan stuktur aktiva akan mengakibatkan kenaikan Struktur Modal sebesar 0,006 .

\section{Koefisien Determinasi}

Tabel 2. Koefisien Determinasi

\begin{tabular}{|c|c|c|c|}
\hline \multicolumn{4}{|c|}{ Model Summary ${ }^{b}$} \\
\hline Mod & $\begin{array}{c}\mathrm{R} \\
\text { Square }\end{array}$ & $\begin{array}{l}\text { Adjusted } \\
\text { R Square }\end{array}$ & $\begin{array}{l}\text { Std.Error of } \\
\text { the Eatimate }\end{array}$ \\
\hline
\end{tabular}

\begin{tabular}{lllll}
\hline 1 &, $398^{\mathrm{a}}$ &, 158 &, 146 &, 99890 \\
\hline
\end{tabular}

Berdasakan tabel Adjusted $\mathrm{R}$

Square memperoleh nilai 0,146 $(14,6 \%)$ dari varietas variabel terkait struktur modal yang bisa dijabarkan bagi setiap variabel terbuka sedangkan selebihnya $\quad 85,4 \% \quad(100 \%-14,6 \%)$ dijabarkan bagi variabel lainnya diluar dari penelitian, misalnya ROE, GPM, ROI, Cash ratio, dan Quick ratio.

\section{Pengujian Hipotesis Secara Simultan (Uji F)}

Tabel 3. Uji F

\begin{tabular}{|c|c|c|c|c|c|c|}
\hline \multicolumn{7}{|c|}{ ANOVA $^{\mathrm{a}}$} \\
\hline Model & & $\begin{array}{c}\text { Sum of } \\
\text { Squares }\end{array}$ & $\overline{\mathrm{Df}}$ & $\begin{array}{c}\text { Mean } \\
\text { Squares }\end{array}$ & $\mathrm{F}$ & Sig. \\
\hline & $\begin{array}{l}\text { Regressi } \\
\text { on }\end{array}$ & 38,575 & 3 & 12,858 & 12,887 &, $000^{\mathrm{b}}$ \\
\hline & Residual & 205,546 & 206 & ,998 & & \\
\hline & Total & 244,121 & 209 & & & \\
\hline
\end{tabular}

diperoleh nilai uji signifikasi simultan (Uji F) yakni $F_{\text {hitung sebesar } 12,887 .}$ Pada taraf partikelir $1(\mathrm{df} 1)=3$, dan 
taraf partikelir $2(\mathrm{df} 2)=206$, angka $\mathrm{F}_{\text {tabel }}$ atas tingkat relevan (signifikan) 0,05 yaitu 2,65 maka $F_{\text {hitung }}$ $=12,887>\mathrm{F}_{\text {tabel }}=2,65$ pada taraf relevan 0,000 . Dikarenakan profitabilitas signifikan lebih kecil dari $0,000<0,05$, hingga $\mathrm{H}_{\mathrm{a}}$ diterima sebab itu secara simultan profitabilitas (ROA), likuiditas (CR), dan struktur aktiva berpengaruh terhadap Struktur modal pada perusahaan sub sektor manufaktur yang terdaftar di BEI periode 20152017.

\section{Pengujian Hipotesis Secara Parsial (Uji-t)}

Tabel 4. Uji T

\begin{tabular}{|c|c|c|c|c|c|c|}
\hline & \multicolumn{5}{|c|}{ Coefficients $^{a}$} \\
\hline \multirow{2}{*}{\multicolumn{2}{|c|}{ Model }} & \multicolumn{2}{|c|}{$\begin{array}{l}\text { Unstandardized } \\
\text { Coefficients }\end{array}$} & \multirow{2}{*}{$\begin{array}{l}\text { Standar } \\
\text { dized } \\
\text { Coeffici } \\
\text { ents } \\
\text { Beta }\end{array}$} & \multirow[t]{2}{*}{$\bar{T}$} & \multirow[t]{2}{*}{ Sig. } \\
\hline & & $\bar{B}$ & $\begin{array}{l}\text { Std.Er } \\
\text { ror }\end{array}$ & & & \\
\hline \multirow{4}{*}{1} & (Constant) &,- 277 & ,230 & & $-1,205$ & ,230 \\
\hline & $\begin{array}{l}\text { LnProfitabil } \\
\text { itas }\end{array}$ &,- 078 & ,054 &,- 093 & $-1,443$ & , 150 \\
\hline & $\begin{array}{l}\text { LnLikuidita } \\
\text { s }\end{array}$ &,- 555 & ,096 &,- 376 & $-5,791$ &, 000 \\
\hline & $\begin{array}{l}\text { LnStruktur } \\
\text { Aktiva }\end{array}$ & ,006 & ,112 & ,003 & ,053 & ,958 \\
\hline
\end{tabular}

Berdasarkan dari hasil Uji-t:

1. Pengaruh Profitabilitas $\left(X_{1}\right)$ terhadap Struktur modal (Y) diperoleh $t_{\text {hitung }}$ sebesar 1,443 atas angka relevan $0,150>0,05$. Jumlah $t_{\text {hitung }}<t_{\text {tabel }}$ atau $1,443<1,9714$ sehingga disimpulkan jika hipotesis preferensi $\left(\mathrm{H}_{\mathrm{a}}\right)$ ditolak dan hipotesis nol $\left(\mathrm{H}_{0}\right)$ diterima oleh sebab itu, secara parsial profitablitas (ROA) tidak memiliki pengaruh dan tidak signifikan terhadap Struktur modal pada perusahaan Sub sektor manufaktur di BEI periode 20152017. Dengan demikian hipotesis tidak sejalan dengan penelitian.

2. Pengaruh likuiditas $\left(\mathrm{X}_{2}\right)$ terhadap struktur modal (Y) didapat thitung sejumlah $-5,791$ atas tingkat relevan $0,000<0,05$. Jumlah $t_{\text {hitung }}>t_{\text {tabel }}$ atau $5,791>1,9714$ bahwa preferensi $\left(\mathrm{H}_{\mathrm{a}}\right)$ diterima dan hipotesis nol $\left(\mathrm{H}_{0}\right)$ ditolak artinya secara parsial Likuiditas (Current Ratio) mempunyai pengaruh negatif serta signifikan terhadap Struktur modal pada perusahaan sub sektor manufaktur di BEI periode 20152017. Oleh karena itu hipotesis sejalan dengan penelitian.

3. Pengaruh struktur aktiva $\left(\mathrm{X}_{3}\right)$ terhadap struktur modal (Y) diperoleh $t_{\text {hitung }}$ sebesar 0,053 dengan nilai signifikan $0,958>0,05$. Nilai $t_{\text {hitung }}<\mathrm{t}_{\text {tabel }}$ atau $0,053<1,9714$ maka hipotesisi preferensi $\left(\mathrm{H}_{\mathrm{a}}\right)$ ditolak dan hipotesis nol $\left(\mathrm{H}_{0}\right)$ diterima artinya, secara parsial struktur aktiva tidak memiliki pengaruh negatif dan tidak relevan terhadap Struktur modal pada perusahaan Sub sektor manufaktur di BEI periode 2015-2017. Dengan demikian hipotesis tidak sejalan dengan penelitian.

\section{Pengaruh Profitabilitas terhadap Struktur Modal}

Diperoleh nilai dari hasil perhitungan thitung $<$ tabel atau $1,443<1,9714$ bernilai negatif dengan demikian Profitabilitas (Return on Assets) tidak memiliki pengaruh yang relevan terhadap struktur modal pada perusahaan Sub sektor manufaktur di BEI periode 2015-2017 tidak diterima. Hasil dari penelitian tersebut, profitabilitas (ROA) belum menggambarkan pengembalian laba dan penggunaan seluruh aktiva/asset. Jadi dapat dikatakan kurang menggerakkan administrasi dalam menambahkan aktiva jika jumlah ROA yang diharapkan kelewat tinggi

Hasil pada penelitian ini berbeda dari yang diteliti Farisa dan Widati (2017) yang membuktikan, jika profitabilitas tidak mempunyai pengaruh negatif serta tidak relevan terhadap struktur modal. Juga observasi 
ini berbeda dengan observasi yang telah dilakukan Widodo \& Djawahir (2014), Santoso \& Priantinah (2016) dan Eviani (2015) yang membuktikan jika profitabilitas memang berpengaruh negatif serta substansial terhadap struktur modal. Namun hasil penelitian ini memperkuat penelitian Anwar et.al (2014), Pertiwi \& Darmayanti (2018) yang mengungkapkan jika profitabilitas tidak ada pengaruh relevan terhadap struktur modal.

\section{Pengaruh Likuiditass Terhadap Struktur Modal}

Hasil estimasi didapat senilai $t_{\text {hitung }}>t_{\text {tabel }}$ atau 5,791 $>1,9714$ dengan begitu Likuiditas (Current Ratio) mempunyai pengaruh yang negatif serta relevan terhadap struktur modal pada perusahaan Sub sektor manufaktur di Bursa Efek Indonesia periode 2015-2017. Hingga mendukung hipotesis jika memang likuiditas berpengaruh terhadap struktur modal.

Apabila suatu perusaaan memegang peringkat Likuiditas yang tinggi, situasi ini dapat dikatakan bahwa current assets yang dipunyai oleh suatu perusahaan lebih tinggi daripada utang yang harus dipenuhi. Perusahaan mampu memenuhui kebutuhan investasi yang dapat membayar kewajibannya dengan tepat waktu, perusahaan cenderung memilih pembiayaan yang bersumber dari internal funds perusahaan lebih dulu sebelum memanfaatkan pendanaan yang bersumber dari dana external.

Hasil yang didapat pada penelitian ini membantu pendapat observasi yang diteliti oleh Eviani (2015), dan Farisa \& Widati (2017) yang membuktikan jika likuiditas berpengaruh negatif serta substansial terhadap struktur modal. Namun penelitian ini berbeda dengan observasi yang dilakukan Wulandari (2013), menjelaskan jika likuiditas berpengaruh negatif tapi tidak relevan terhadap Struktur modal.

\section{Pengaruh Struktur Aktiva Terhadap Struktur Modal}

Hasil estimasi memperoleh angka $t_{\text {hitung }}<t_{\text {tabel }}$ atau $0,053<1,9714$ dengan demikian struktur aktiva tidak ada pengaruh serta tidak signifikan terhadap struktur modal pada perusahaan sub sektor manufaktur yang terdaftar di Bursa Efek Indonesia periode 2015-2017. Yang artinya hipotesis $\mathrm{X}_{3}$ tidak diterima yang mengungkapkan jika struktur aktiva berpengaruh terhadap struktur modal.

\begin{tabular}{llrr}
\multicolumn{2}{c}{ Masalah tersebut } & memicu \\
apabila suatu & industri & tidak \\
memperhatikan struktur & aktiva \\
terutama aktiva tetapnya & dalam \\
membuat kebijakan utang & baru.
\end{tabular}
Umumnya perusahaan sebagian besar dananya tertanam pada fixed assets akan memprioritaskan kebutuhan dananya dari ekuitas pemilik, sedangkan utang sebagai tambahan. Perusahaan yang aktivanya semakin banyak dan terdiri dari current assets akan lebih mementingkan pemenuhan kepentingan dengan utang.

Penelitian ini tidak memanggul riset yang dikerjakan oleh Santoso \& Priantinah (2016), Farisa \& Widati (2017) yang membuktikan bilamana struktur aktiva berpengaruh negatif juga substansial terhadap struktur modal. Akan tetapi penelitian ini memperkuat hasil penelitian Eviani (2015) yang menegaskan jika struktur aktiva tidak memliki pengaruh positif juga tidak signifikan terhadap Struktur modal. 


\section{PENUTUP}

\section{Kesimpulan}

1. Variabel profitabilitas (ROA) membuktikan secara parsial bahwa tiada pengaruh struktur modal pada perusahaan sub sektor manufaktur yang terdaftar di BEI periode 20152017.

2. Variabel likuiditas (CR) membuktikan secara parsial bahwa memiliki pengaruh negatif terhadap struktur modal pada perusahaan sub sektor manufaktur yang terdaftar di BEI periode 2015-2017.

3. Variabel struktur aktiva membuktikan secara parsial bahwa tidak adanya pengaruh struktur modal pada perusahaan sub sektor manufaktur yang terdaftar di BEI periode 2015-2017.

4. Yang menjadi variabel terbuka yakni profitabilitas (ROA), likuiditas (CR), dan struktur aktiva membuktikan hasil pengujian secara simultan tidak adanya pengaruh yang sugnifikan terhadap struktur modal pada perusahaan sub sektor manufaktur yang terdaftar di BEI periode 2015-2017.

Sebesar $14,6 \%$ dari varietas variabel terkait ialah struktur modal yang mampu dideskripsikan oleh variabel independen selebihnya 85,4\% (100\%$14,6 \%$ ) dijabarkan oleh variabel lainnya diluar dari penelitian misalnya, ROE, GPM, ROE, Cash Ratio, dan Quick Ratio.

\section{Saran}

1. Kepada pihak investor, sebelum memutuskan untuk menanam modalnya pada perusahaan, sebaiknya memperhitungkan faktor yang mempengaruhi Struktur Modal. Sebaiknya investor bukan hanya memperhitungkan profit perusahaan tetapi juga aspek lainnya seperti, ROA, Current Ratio, dan Struktur aktiva.
2. Bagi Perusahaan, di sub sektor manufaktur di BEI diharapkan dapat meningkatkan profitability, structure assets, dan kinerja keuangan, sehingga target yang diperoleh perusahaan dapat tercapai secara optimal.

3. Bagi peneliti berikutnya, disarankan dapat menggunakan faktor internal lainnya yang mempengaruhi Struktur Modal selain ROA, Current Ratio, dan Struktur Aktiva misalnya ROE, GPM, ROI, Cash Ratio, dan Quick Ratio.

\section{DAFTAR PUSTAKA}

Anwar, J., Andini, R., \& Raharjo, K. (2015). Pengaruh Ukuran Perusahaan, Resiko Bisnis, Pertumbuhan Asset, Profitabilitas, Struktur Kepemilikan dan Struktur Aktiva Terhadap Struktur Modal Pada Perusahaan Manufaktur di Bursa Efek Indonesia Periode 2010-2013. Journal of Accounting, 1(1).

Cahyani, N. I., \& Handayani, N. (2017). Pengaruh Profitabilitas, Likuiditas, Size, Kepemilikan Institusional, Dan Tangibility Terhadap Struktur Modal. Jurnal Ilmu dan Riset Akuntansi (JIRA), 6(2).

Eviani, A. D. (2016). Pengaruh struktur aktiva, pertumbuhan penjualan, dividend payout ratio, likuiditas dan profitabilitas terhadap struktur modal. Jurnal Akuntansi dan Sistem Teknologi Informasi, 11(2).

Farisa, N. A., \& Widati, L. W. (2017). Analisa Profitabilitas, Likuiditas, Pertumbuhan Penjualan, Struktur Aktiva Dan Kebijakan 
Dividen Terhadap Struktur Modal.

Santoso, Y., \& Priantinah, D. (2016). Pengaruh Profitabilitas, Ukuran Perusahaan, Struktur Aktiva, Likuiditas dan Growth Opportunity terhadap Struktur Modal Perusahaan. Jurnal Profita: Kajian Ilmu Akuntansi, 4(4).

Widodo, M. W., \& Djawahir, A. H. (2014). Pengaruh Tangibility, Profitabilitas, Pertumbuhan Perusahaan, Non Debt Tax Shields, Cash Holding dan Ukuran Perusahaan terhadap Struktur Modal Perusahaan (Studi pada Perusahaan Manufaktur yang Listing di BEI Tahun 20102012). Jurnal Aplikasi Manajemen, 12(1), 143-150.

Wulandari, D. R. (2013). Pengaruh Profitabilitas, Operating Leverage, Likuiditas terhadap nilai perusahaan dengan struktur modal sebagai intervening. Accounting Analysis Journal, 2(4). 